\title{
PEPTIDES AND BACTERIAL GROWTH
}

\section{The Nutritional Requirements of Lactobacillus delbrueckiI}

\author{
VINCENT J. PETERS AND ESMOND E. SNELL
}

The Biochemical Institute and the Department of Chemistry, University of Texas, and the Clayton Foundation for Research, Austin, Texas

Received for publication July 16, 1953

Lactobacillus delbrueckii, strain 730 (ATCC 9649), is representative of a large group of lactic acid bacteria that is more fastidious in its nutritional requirements than are those organisms (e.g., Lactobacillus arabinosus, Streptococcus faecalis) commonly used for assay of vitamins and amino acids. Previous nutritional investigations with this organism (McNutt and Snell, 1950; Kitay et al., 1950) showed it to require pyridoxamine phosphate, thymidine, and an unsaturated fatty acid (e.g., oleic acid) for growth in a medium supplied with the usual vitamins and amino acids. The requirement for thymidine was specific; vitamin $\mathbf{B}_{12}$, reducing agents, or other desoxyribosides failed to substitute for it. Growth of the organism was greatly speeded by enzymatic digests of casein although these were not essential for slow growth (Kitay and Snell, 1950).

In more recent studies, unphysiologically high amounts of L-histidine or small amounts of histidine peptides (e.g., carnosine) were shown to duplicate the growth promoting action of enzymatic protein digests for this organism (Peters et al., 1953). In a slightly modified medium, serine peptides were required in addition to histidine peptides for rapid growth (Prescott et al., 1953).

Because of the infrequency with which such requirements have been reported, it appeared worthwhile to determine the nutritional requirements of this organism in more detail. Results of this investigation are presented below.

\section{METHODS}

L. delbrueckii, strain 730 (ATCC 9649), was the organism employed. The handling of cultures and assay techniques were the same as reported by Peters et al. (1953). The synthetic basal medium specified there contains each of the amino acids found in complete proteins, together with $B$ vitamins and other substances required by the test organism. It was supplemented with 167 $\mathrm{mg}$ of I-histidine hydrochloride per $100 \mathrm{ml}$ to eliminate the requirement for histidine peptides and permit a rapid rate of growth on a chemically defined medium. Culture tubes contained $6 \mathrm{ml}$ of the diluted medium.

\section{RESULTS}

The nutritional requirements of $L$. delbrueckii. The medium described above is "complete" in the sense that it permits rapid and extensive growth of $L$. delbrueckii. Each of its components was omitted individually, and the effect of such omission on the rate and extent of growth of $L$. delbrueckii was noted. In table 1 the substances essential for growth are listed. Except as indicated, omission of any one of these substances from the basal medium prevents growth, even after prolonged incubation. Most of the individual substances found necessary for growth have been found previously to be required by one or another species of lactic acid bacteria, although in different combinations (Snell, 1952). Only those requirements possessing some unusual feature are discussed below.

It should be noted (table 1 ) that both $\mathrm{D}$ - and L-alanine are listed as being required for growth. If either the $\mathrm{L}$ - or the D-isomer is supplied singly, pyridoxamine phosphate will eliminate the requirement for the remaining isomer of alanine. Obviously, $L$. delbrueckii contains alanine racemase, similar in action to that shown by Wood and Gunsalus (1951) to be present in cells of $S$. faecalis, and which is functional only when vitamin $B_{6}$ is supplied in a form utilizable by this organism. If both $\mathbf{D}$ - and L-alanine are supplied, no vitamin $B_{6}$ is required by $L$. delbrueckii provided all other amino acids are supplied. In the presence of a single isomer of $\alpha$-alanine ( $D$ - or $\mathrm{L}-)$, vitamin $\mathrm{B}_{6}$ is required to permit the formation of the other isomer and can be supplied in any one of the following forms per $6 \mathrm{ml}$ of me- 
TABLE 1

Essential nutrients for Lactobacillus delbrueckii, strain $9649^{*}$

$\begin{array}{ll}\text { A. Amino acids } & \text { C. Purine and pyrimidine bases } \\ \text { D-Alanine } & \text { Hypoxanthine } \\ \text { U-Alanine† } & \\ \text { L-Threonine } & \text { D. Inorganic ions } \\ \text { L-Tyrosine } & \mathbf{K}^{+} \\ \text {L-Valine } & \text { PO } \\ \text { L-Tryptophan } & \text { Mg } \\ \text { L-Cystine } & \\ \text { L-Serine } & \text { E. Miscellaneous } \\ \text { L-Aspartic acid } & \text { Fermentable carbohydrate (e.g., glucose) } \\ \text { L-Glutamic acid } & \text { Sodium acetate\$ } \\ \text { L-Arginine } & \text { Oleic acid } \\ \text { L-Lysine } & \text { Thymidine } \\ \text { L-Leucine } & \\ \text { L-Phenylalanine } & \\ \text { L-Histidine } & \\ \text { B. Vitamins } & \\ \text { Pantothenic acid } \ddagger & \\ \text { Nicotinic acid } & \\ \text { Ribofiavin } & \\ \text { Pyridoxamine phosphate } \dagger & \end{array}$

* Concentrations of these normally employed in the basal medium are given by Peters et al. (1953). Nonessential components included in this medium are glycine, isoleucine, methionine, proline, biotin, folic acid, $p$-aminobenzoic acid, thiamin, $\mathrm{Fe}^{++}, \mathrm{Ca}^{++}$, and $\mathrm{Mg}^{++}$. The specificity of these requirements is considered in the text.

$\dagger$ Pyridoxamine phosphate is not required if both $D$ - and L-alanine are supplied, see text.

$\ddagger$ Pantethine is much more active than pantothenic acid for this organism (Craig and Snell, 1951). $\$$ Slow growth occurs in the absence of this substance; it is required, however, for rapid and heavy growth.

dium: pyridoxamine phosphate, 10 to $25 \mathrm{~m} \mu \mathrm{g}$; pyridoxal phosphate, 50 to $125 \mathrm{~m} \mu \mathrm{g}$; pyridoxamine dihydrochloride, 0.5 to $1 \mathrm{mg}$; or pyridoxal hydrochloride, 1 to $2 \mathrm{mg}$. Pyridoxamine phosphate is thus 50,000 times more active than the unphosphorylated vitamin, and since the latter does not occur naturally in the amounts required for growth, pyridoxamine phosphate must be considered the growth factor (McNutt and Snell, 1950).

Because of these relationships, an assay method for either D- or L-alanine can be devised by omitting both pyridoxamine phosphate and the form of alanine to be determined from the medium and removing pyridoxamine phosphate and pyridoxal phosphate from the samples to be assayed. Alternatively, in the presence of either $\mathbf{D}$ - or L-alanine, it is possible to assay for pyridoxamine phosphate. ${ }^{1}$ Even large amounts of pyridoxamine

1 Pyridoxal phosphate has about one-fifth the activity of pyridoxamine phosphate (McNutt and phosphate do not permit growth in the absence of $D$ - and L-alanine except after prolonged incubation periods (40-60 hours), i.e., the organism apparently lacks the ability to transform pyruvate (presumably formed as an intermediate in the formation of lactate) to alanine at a rate sufficient for rapid growth.

Hypoxanthine and uracil are essential for the growth of $L$. delbrueckii. In the absence of hypoxanthine, the simultaneous addition of adenine and guanine to the otherwise complete medium promotes rapid growth similar to that obtained with hypoxanthine. Guanine alone (but not adenine alone) permits much slower growth.

Snell, 1950) but can be largely converted to pyridoxamine phosphate by autoclaving samples with the medium. For determination of pyridoxamine phosphate, it is most practicable to substitute an acid or enzymatic digest of casein, both of which supply L-alanine, for the mixture of amino acids of the basal medium. 


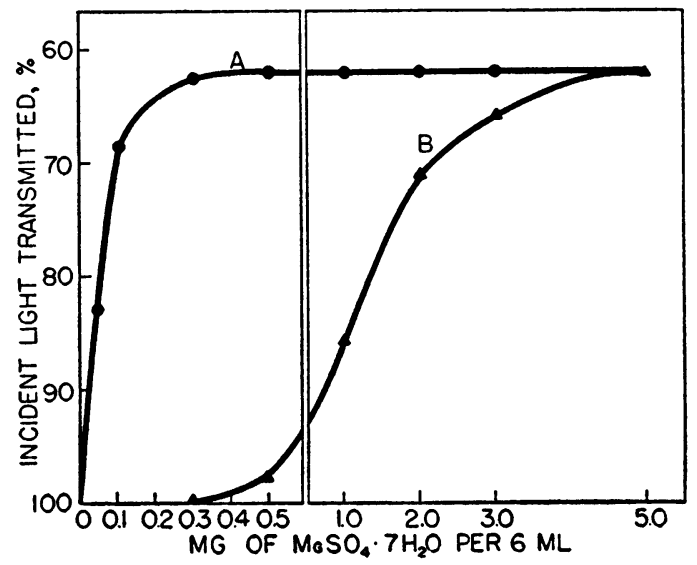

Figure 1. The response of Lactobacillus delbrueckii to $\mathrm{Mg}^{++}$in the presence and absence of other divalent cations. Incubation time, 19 hours.

A. $\mathrm{Mn}^{++}, \mathrm{Ca}^{++}$, and $\mathrm{Fe}^{++}$present in excess (Peters et al., 1953).

B. $\mathrm{Mn}^{++}, \mathrm{Ca}^{++}$, and $\mathrm{Fe}^{++}$omitted.

In the absence of sodium acetate, $L$. delbrueckii grows very slowly. 2 The addition of small amounts of acetate to a phosphate buffered medium greatly increases the rate of growth. This stimulatory action of acetate is similar to but more pronounced than that first demonstrated by Snell et al. $(1937 a, b)$ for another strain of $L$. delbrueckii and for $L$. casei. In contrast to its effect in $L$. casei, the "acetate replacing factor", lipoic acid (Snell and Broquist, 1949; Reed et al., 1951), does not eliminate the requirement of $L$. delbrueckii, strain 9649, for acetate when added either alone or together with thiamin ( $c f$ Reed and DeBusk, 1952).

As expected from the requirements of other lactic acid bacteria (MacLeod and Snell, 1947), $\mathrm{K}^{+}$and $\mathrm{PO}_{4}^{-}$are required by $L$. delbrueckii. In contrast to the organisms previously examined, however, $L$. delbrueckii requires large amounts of $\mathbf{M g}^{++}$for growth, a requirement that is decreased greatly by the simultaneous presence of $\mathrm{Mn}^{++}$, and to a lesser extent by that of $\mathrm{Ca}^{++}$ and $\mathrm{Fe}^{++}$(figure 1). In the presence of adequate $\mathrm{Mg}^{++}$, none of the latter three ions appears essential for growth although very small but essential amounts may be present as contaminants in the medium. This is the converse of the situation previously observed in $L$. arabinosus, which appeared to require large amounts of $\mathrm{Mn}^{++}$for

2 In experiments in which acetate was omitted, the buffer capacity of the medium was increased by the addition of 0.5 per cent $\mathrm{KH}_{2} \mathrm{PO}_{4}$. growth, but no $\mathrm{Mg}^{++}$. In the latter instance, the $\mathrm{Mn}^{++}$requirement was decreased greatly by the addition of $\mathrm{Mg}^{++}$and $\mathrm{Ca}^{++}$(MacLeod and Snell, $1950 a, b)$. Examination of figure 1 makes it clear that $\mathrm{Mn}^{++}, \mathrm{Ca}^{++}$, or $\mathrm{Fe}^{++}$would greatly increase growth if added to a medium low in $\mathrm{Mg}^{++}$; they appear nonessential and nonstimulatory only when $\mathrm{Mg}^{++}$is present in excess. Substances added to the basal medium that proved nonessential for growth of $L$. delbrueckii are listed in a footnote to table 1. Some of these stimulated the rate or increased the amount of growth slightly. The "nonessential" classification of isoleucine, methionine, glycine, and proline may be in error; the first three of these frequently occur as contaminants in commercially available amino acids and may have been supplied in the amounts necessary in this way. Their addition increased growth obtained during short incubation periods.

Peptides and growth of $L$. delbrueckii.

A. The comparative effectiveness of partial vs. complete hydrolyzates of casein in supplying indi-

\section{TABLE 2}

The comparative activities of partial and complete hydrolyzates of protein in supplying individual essential amino acids for Lactobacillus delbrueckii

\begin{tabular}{|c|c|}
\hline AMTNO ACD & $\begin{array}{c}\text { ACTIVITY RATIO } \\
\text { (PARTLL } \\
\text { HYDROLYZATI/ } \\
\text { CONRLYTI } \\
\text { HYDROLYZATI) }\end{array}$ \\
\hline Alanine $\ldots \ldots \ldots \ldots \ldots \ldots \ldots$ & 1.0 \\
\hline Arginine $\ldots \ldots \ldots \ldots \ldots \ldots \ldots \ldots$ & 1.0 \\
\hline Aspartic acid $\ldots \ldots \ldots \ldots \ldots \ldots$ & 1.1 \\
\hline Cystine $\ldots \ldots \ldots \ldots \ldots \ldots \ldots \ldots$ & 1.9 \\
\hline Glutamic acid $\ldots \ldots \ldots \ldots \ldots \ldots \ldots$ & 1.8 \\
\hline Glycine................. & 3.0 \\
\hline Histidine $\ldots \ldots \ldots \ldots \ldots \ldots$ & 4.8 \\
\hline Isoleucine... & 4.2 \\
\hline Lysine. . . . . . . . . . . . & 1.0 \\
\hline Leucine..... . & 1.8 \\
\hline Methionine.. & 4.0 \\
\hline Phenylalanine... & 2.5 \\
\hline Proline......... & 1.6 \\
\hline 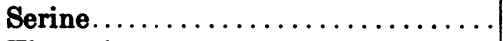 & 10.0 \\
\hline Threonine........... & 1.6 \\
\hline Tyrosine....... & 3.4 \\
\hline Valine $\ldots \ldots \ldots \ldots \ldots \ldots$ & 3.3 \\
\hline
\end{tabular}

* The activity ratio was calculated by dividing the weight of the complete casein hydrolyzate required to permit half maximum growth by the weight of the partial hydrolyzate required to permit the same amount of growth (figure 2). 


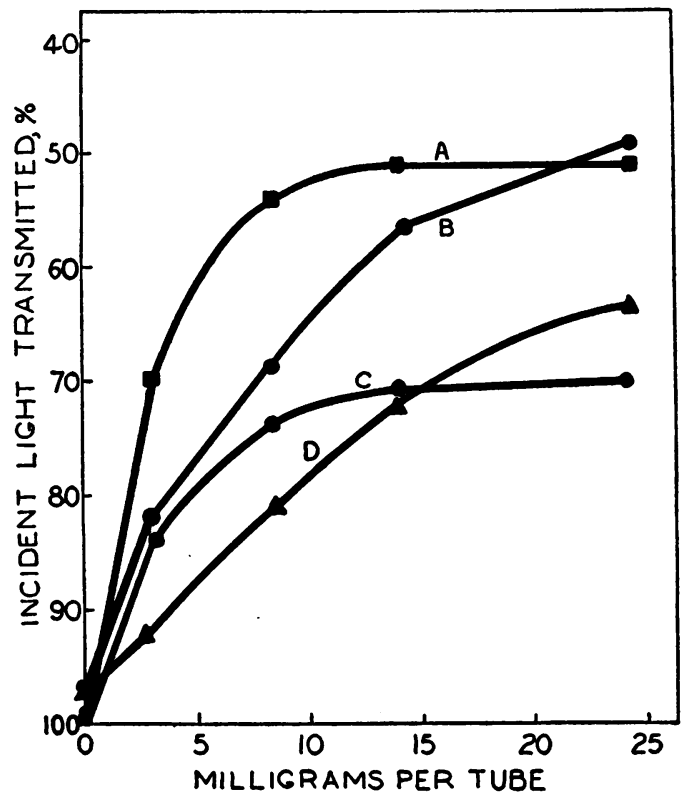

Figure 2. The comparative activities of partial or complete hydrolyzates of casein as sources of valine or phenylalanine for Lactobacillus delbrueckii. Incubation time, 19 hours.

A. Partial hydrolyzate substituted for valine.

B. Partial hydrolyzate substituted for phenylalanine.

C. Complete hydrolyzate substituted for valine.

D. Complete hydrolyzate substituted for phenylalanine.

vidual amino acids for growth. The inability of $L$. delbrueckii to utilize effectively low concentrations of histidine (Peters et al., 1953) or serine (Prescott et al., 1953) has been noted previously. In each case, peptides of these amino acids were utilized in low concentrations; the differences in efficiency of utilization were of such a magnitude that partial hydrolyzates of proteins stimulated growth when added to media containing an excess of each of the free amino acids. To determine if similar differences of smaller magnitude existed with other essential amino acids, the latter were omitted individually from the basal medium, and the effectiveness of a completely hydrolyzed casein $^{3}$ compared with that of partially hydro-

3 Vitamin-free casein (Labco, 28 g) was partially hydrolyzed by autoclaving with $400 \mathrm{ml}$ of $1 \mathrm{~N}_{2} \mathrm{SO}_{4}$ for 5 hours at 15 pounds pressure. The average chain length calculated for the peptides of this hydrolyzate was 1.5 . A second $28 \mathrm{~g}$ portion

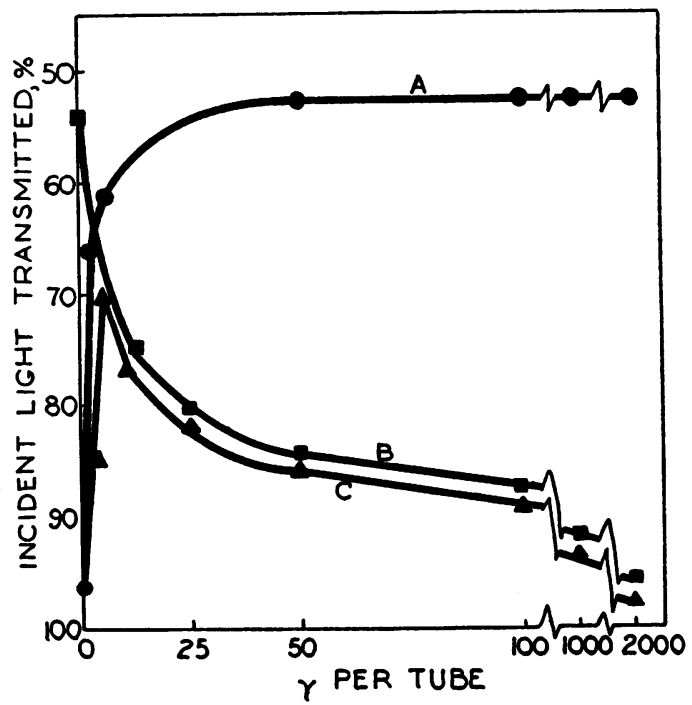

Figure s. The comparative activities of $\mathrm{L}$ tryptophan (curve A) and glycyl-L-tryptophan (curve C) in supporting growth of Lactobacillus delbrueckii in a tryptophan-free medium. Curve $B$ shows the response to glycyl-L-tryptophan in the same medium supplemented with an excess (1.2 $\mathrm{mg}$ per $6 \mathrm{ml}$ ) of DL-tryptophan. Incubation time, 18 hours.

lyzed casein ${ }^{3}$ as a source of the missing amino acid. In most cases (table 2 and figure 2) the partial hydrolyzate, which contains a portion of its amino acids as peptides, ${ }^{\mathbf{3}}$ is more active than the complete hydrolyzate, which contains only free amino acids.

B. Inhibition of growth by peptides and its counteraction by partially hydrolyzed proteins. 1. Glycyl$L$-tryptophan. At concentrations below $20 \mu \mathrm{g}$ per $6 \mathrm{ml}, L$. delbrueckii utilizes glycyl-L-tryptophan as a source of tryptophan while at higher concentrations the peptide becomes inhibitory (figure 3). This inhibition is not alleviated by free tryptophan. With longer incubation times, maximum growth is achieved eventually in the presence of the peptide. Partially hydrolyzed casein and yeast extract effectively prevent the

of casein was hydrolyzed completely by auto-

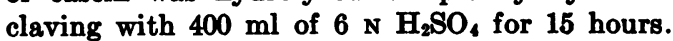
Excess sulfate ion was removed from both hydrolyzates with $\mathrm{Ba}(\mathrm{OH})_{2}$. They were' adjusted then to $\mathrm{pH} 3.0$ with sulfuric acid, stirred for $\mathbf{0 . 5}$ hour with $14 \mathrm{~g}$ of activated carbon (Darco G-60), filtered, and diluted to appropriate concentrations for use. 


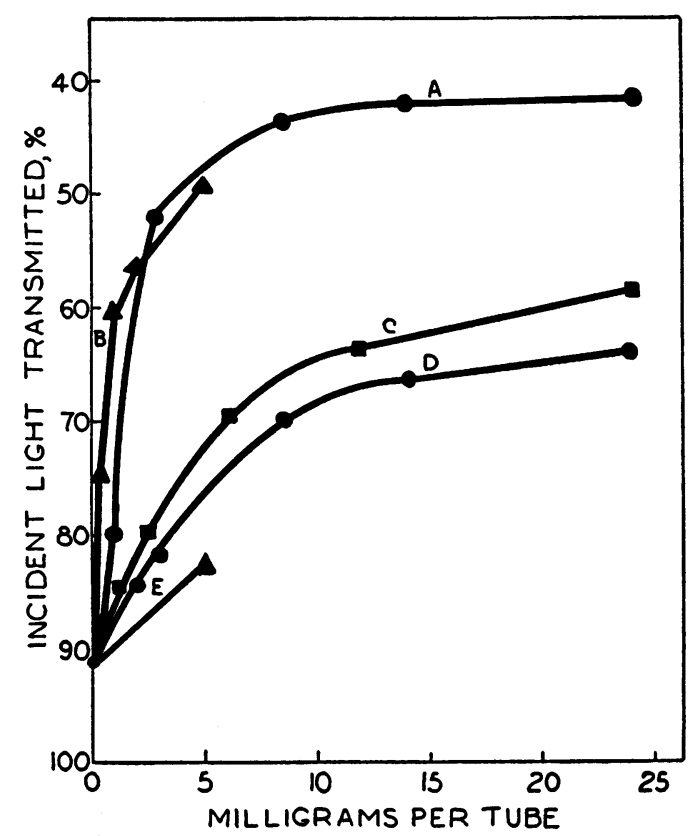

Figure 4. The comparative activities of a partially hydrolyzed casein (curve A), yeast extract (B), a mixture of equal amounts of L-histidine, L-glutamic acid, DL-isoleucine, L-lysine, and L-cystine (C), completely hydrolyzed casein (D), and DL-isoleucine (E) in preventing the inhibitory action of glycyl-L-tryptophan. The complete medium was supplemented with $200 \mu \mathrm{g}$ of this peptide per $6 \mathrm{ml}$. In the absence of glycyl-Ltryptophan, growth equivalent to a light transmission of 53 (curve $B$, figure 3) was obtained. Incubation time, 16 hours.

inhibition caused by glycyl-L-tryptophan (figure 4). Completely hydrolyzed casein is much less effective. To determine which amino acids of the complete hydrolyzate were effective, eighteen amino acids were tested individually at increased concentrations. Of these, glutamic acid, histidine, leucine, isoleucine, lysine, and cystine each showed slight activity, similar to that shown for isoleucine in figure 4. A mixture of these six amino acids is slightly more effective than an equal weight of the completely hydrolyzed casein (figure 4) but did not approach yeast extract or the partially hydrolyzed casein in effectiveness. The compounds in the partial hydrolyzate that prevent inhibition by glycyl-L-tryptophan almost certainly are peptides; their identity is unknown.

2. Glutathione. Low concentrations of gluta-

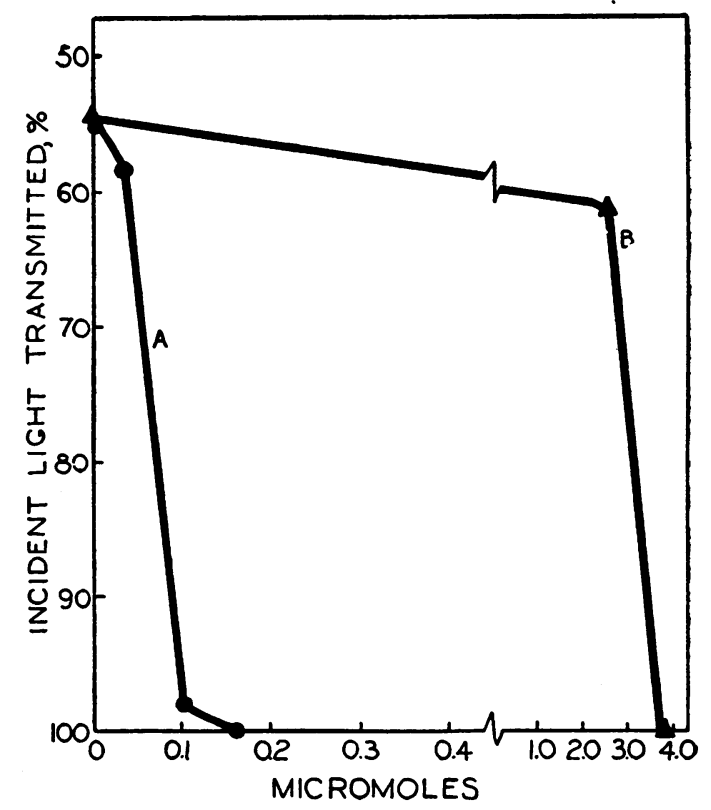

Figure 5. Inhibition of growth of Lactobacillus delbrueckii in the complete medium by glutathione (A) and by colloidal sulfur (B). Incubation time, 18, hours.

thione (10 to $30 \mu \mathrm{g}$ per $\mathrm{ml}$ ) markedly inhibit growth of $L$. delbrueckii during short incubation periods (figure 5). No difference in inhibitory action was observed whether glutathione was autoclaved with the medium, autoclaved separately and added aseptically, or sterilized by filtration and added aseptically. Reduced glutathione and oxidized glutathione were equally inhibitory. A colloidal suspension of sulfur prepared as described by Schuhardt et al. (1952) was toxic for $L$. delbrueckii, but much less so than glutathione. In contrast to that of glutathione (figure 6), the toxicity of sulfur was not prevented by partial protein hydrolyzates or by yeast extract. Thus, the inhibitions caused by sulfur (Schuhardt et al., 1952) and glutathione in this organism are not of the same nature.

The comparative effects of various supplements on the toxicity of glutathione are shown in figure 6. Partially hydrolyzed casein was much more effective than the completely hydrolyzed casein in preventing the inhibition and was also more effective at low concentrations than yeast extract, strongly indicating that peptides are the effective agents. 


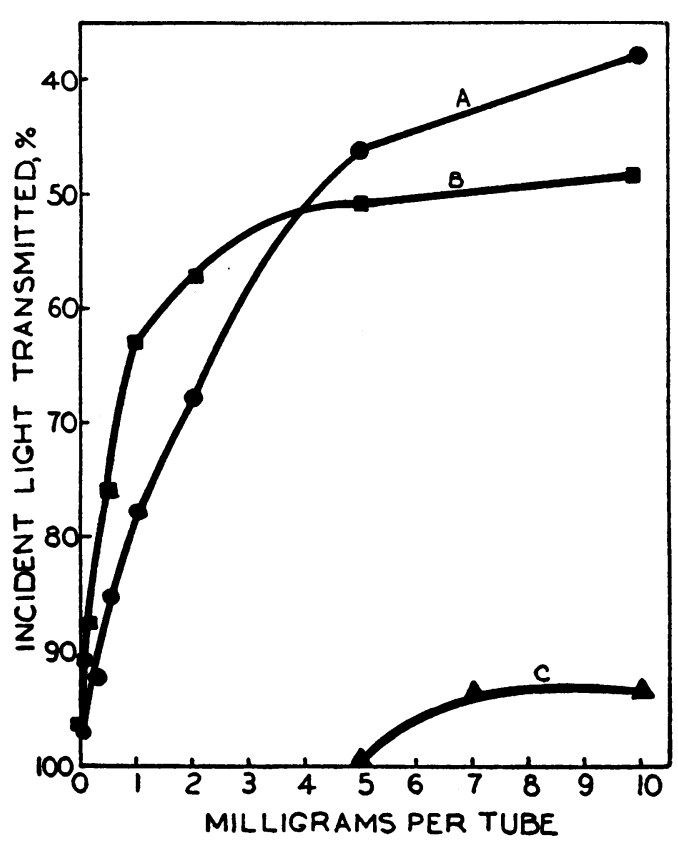

Figure 6. The prevention of glutathione inhibition of Lactobacillus delbrueckii by yeast extract (A), partially hydrolyzed casein (B), and completely hydrolyzed casein (C). Each tube (6 $\mathrm{ml})$ contains $100 \mu \mathrm{g}$ of glutathione. In the absence of glutathione, growth equivalent to a light transmission of 55 (figure 5) occurred without supplements. Incubation time, 19 hours.

\section{DISCUSSION}

The vitamin requirements of $L$. delbrueckii are unusual in that biotin, folic acid, vitamin $B_{12}$, and vitamin $B_{6}$-vitamins essential for many other related organisms - are not required for growth in the "complete" medium used here. In view of the specificity of the requirement for these vitamins (Snell, 1951, 1952), however, failure to observe a requirement for them is not unexpected. Thus, in many other lactic acid bacteria, the requirement for an external source of vitamin $B_{6}$ is eliminated if a complete assortment of L-amino acids and D-alanine is supplied; only under these conditions can $L$. delbrueckii dispense with pyridoxamine phosphate in this medium. Similarly, the requirement for biotin of other lactic acid bacteria is eliminated in otherwise complete media by addition of an unsaturated fatty acid such as oleic acid; that for folic acid by thymine (or thymidine), and that for vitamin $B_{12}$ by thymidine. Since oleic acid (or other appropriate unsaturated fatty acids) and thymidine are required by $L$. delbrueckii even in the presence of the functionally related vitamins, one should not expect the vitamins themselves also to be required. Cells of $L$. delbrueckii grown in this fashion should be extremely low or lacking completely in these vitamins and might be useful in investigations of their role in metabolism.

A distinctive feature of the nutritional requirements of this organism is its efficient utilization of peptides as a source of essential amino acids in contrast to its inability to utilize free amino acids effectively. With only three exceptions (L-alanine, I-lysine, and I-arginine) partial hydrolyzates of protein are more effective sources of individual essential amino acids than are complete hydrolyzates of proteins. Dunn and McClure (1949) have made similar observations with $L$. casei. The impediments to utilization of low concentrations of the free amino acids are not known in most cases. Earlier investigations have shown, however, that D- or L-alanine strongly inhibits utilization of I-serine by this culture of $L$. delbrueckii (Prescott et al., 1953) but is relatively ineffective in inhibiting utilization of peptides of L-serine. This is only one example of a phenomenon that appears to be quite generally true: whenever the assimilation of one free amino acid, $a$, is prevented by an antagonistic amino acid, $b$, appropriate peptides of $a$ are more effective than the free amino acid in overcoming the effects of $b$ (Kihara and Snell, 1952; Hirsch and Cohen, 1953). Such antagonistic relationships between amino acids are quite common and would be most likely to appear where, as in the present experiments, a single amino acid is added in amounts that limit growth to a medium containing an excess of each of the other amino acids. The occurrence of such antagonistic relationships is viewed as the most probable explanation of the results presented here; other mechanisms by which peptides may exert growth effects not shared by their component amino acids are known (Kihara et al., 1952; Peters et al., 1953; Stone and Hoberman, 1953), however, and may be operative in some instances. These latter investigations have emphasized that enhanced activity of a peptide as compared with its component amino acids does not argue in favor of direct utilization of the peptide; such peptides usually can be hydrolyzed by the organisms whose 
growth they promote, and peptides that contain amino acids not found in proteins may be among the most active in promoting growth.

That appropriate simple peptides may be inhibitory to growth has been observed previously by Simmonds et al. $(1947,1951)$. Several peptides of I-leucine that would replace leucine in supporting growth of a mutant of Escherichia coli at low concentrations were found toxic at higher concentrations. The toxicity of glycyl-L-tryptophan and of glutathione for $L$. delbrueckii provides additional instances of this phenomenon; it is of interest that unidentified peptides present in a partial hydrolyzate of protein prevent these inhibitions. These bacteriostatic effects of simple peptides may provide models of the action of certain of the antibiotics. Such antibiotics as bacitracin, gramicidin, and subtilin are peptides that yield a variety of amino acids upon hydrolysis (Carter and Ford, 1950). Gale and Rodwell (1948) reported that penicillin prevented the passage of several amino acids through the cell membrane of Micrococcus pyogenes var. aureus. Simmonds and Fruton $(1950 a, b)$ found that penicillin inhibited the utilization of glycine for the growth of strain SF but had no effect if this essential amino acid is supplied in peptide form. These authors and Hotchkiss (1950) concluded that penicillin was blocking the synthesis of peptides and thus, subsequently, of cellular protein. These findings suggest that the inhibitory action of simple peptides on growth may be allied to that of some of the antibiotics, and that study of the relatively simple model systems would throw light on possible mechanisms by which such antibiotics act.

\section{SUMMARY}

Lactobacillus delbrueckii, strain 9649, requires the amino acids alanine, threonine, tyrosine, valine, tryptophan, cystine, serine, aspartic acid, glutamic acid, arginine, lysine, leucine, phenylalanine, and histidine for growth. Among the vitamins, calcium pantothenate, nicotinic acid, riboflavin, and pyridoxamine phosphate are essential. Pyridoxamine phosphate is not required, however, if both D- and L-alanine are added to an otherwise complete medium. Miscellaneous growth requirements include uracil, hypoxanthine, oleic acid (or other unsaturated fatty acid), thymidine, a fermentable carbohydrate, $\mathbf{M g}^{++}$, $\mathrm{PO}_{4}^{-}$, and $\mathrm{K}^{+}$. Acetate greatly speeds growth and is required for heavy and rapid growth. The specificity of certain of these requirements is discussed and compared briefly with that found for other lactic acid bacteria.

Partially hydrolyzed proteins are considerably more active than completely hydrolyzed proteins as sources of glutamic acid, phenylalanine, isoleucine, valine, methionine, serine, tryptophan, tyrosine, aspartic acid, cystine, threonine, glycine, leucine, proline, and histidine for $L$. delbrueckii. Explanations for this general superiority of peptides over free amino acids in supporting growth are considered.

Glycyl-L-tryptophan and glutathione inhibit growth of $L$. delbrueckii. Partial hydrolyzates of protein effectively prevent these inhibitions; a complete protein hydrolyzate was much less effective, and its activity could be duplicated by appropriate mixtures of amino acids. The activity of the partial protein hydrolyzates is ascribed to the presence therein of unidentified peptides.

\section{REFERENCES}

Carter, H. E., and Ford, J. H. 1950 Biochemistry of antibiotics. Ann. Rev. Biochem., 19, 487-516.

Craig, J. A., and Snell, E. E. 1951 The comparative activities of pantethine, pantothenic acid and coenzyme $A$ for various microorganisms. J. Bact., 61, 283-291.

Dunn, M. S., and MCCuURe, L. E. 1949 The response of Lactobacillus casei to partial hydrolysates of protein. J. Biol. Chem., 184, 223-233.

GaLe, E. F., AND Rodwell, A. W. 1948 Amino acid metabolism of penicillin-resistant staphylococci. J. Bact., 65, 161-167.

Hirsch, M. L., aNd Cohen, G. N. 1953 Aminoacid utilization in bacterial growth. I. Peptide utilization by a leucine-requiring mutant of Escherichia coli. Biochem. J., 63, 25-30.

Hotchisiss, R. D. 1950 Abnormal course of bacterial protein synthesis in the presence of penicillin. J. Exptl. Med., 91, 351-364.

Kihara, H., and Sneld, E. E. 1952 Peptides and bacterial growth. II. L-Alanine peptides and growth of Lactobacillus casei. J. Biol. Chem., 197, 791-800.

Kihara, H., Kratt, O. A., and Snell, E. E. 1952 Peptides and bacterial growth. III. Utilization of tyrosine and tyrosine peptides by Streptococcus faecalis. J. Biol. Chem., 197, 801-807. 
Kitay, E., and Snell, E. E. 1950 Some additional nutritional requirements of certain lactic acid bacteria. J. Bact., 60, 49-56.

Kitay, E., McNutt, W. S., and Snell, E. E. 1950 Desoxyribosides and vitamin $B_{12}$ as growth factors for lactic acid bacteria. J. Bact., 69, 727-738.

MacLeod, R. A., and Snell, E. E. 1947 Some mineral requirements of the lactic acid bacteria. J. Biol. Chem., 170, 351-365.

Macleod, R. A., and Sneld, E. E. 1950a The relation of ion antagonism to the inorganic nutrition of lactic acid bacteria. J. Bact., 69, 783-792.

Macleod, R. A., and SNeld, E. E. 19506 Ion antagonism in bacteria as related to antimetabolites. Ann. N. Y. Acad. Sci., 62, 1249-1259.

McNutt, W. S., and Sneld, E. E. 1950 Pyridoxal phosphate and pyridoxamine phosphate as growth factors for lactic acid bacteria. J. Biol. Chem., 182, 557-567

Peters, V. J., Prescott, J. M., and Snell, E. E. 1953 Peptides and bacterial growth. IV. Histidine peptides as growth factors for Lactobacillus delbrueckii 9649. J. Biol. Chem., 202, 521-532.

Prescott, J. M., Peters, V. J., and Sneld, E. E. 1953 Peptides and bacterial growth. V. Serine peptides and growth of Lactobacillus delbrueckii 9649. J. Biol. Chem., 202, 533540.

Reed, L. J., ANd DeBusk, B. G. 1952 Lipothiamide and its relation to a thiamin coenzyme required for oxidative decarboxylation of alpha-keto acids. J. Am. Chem. Soc., 74, 3457.

Reed, L. J., DeBusk, B. G., Gunsalus, I. C., aND Hornberger, C. S., JR. 1951 Crystalline $\alpha$-lipoic acid: A catalytic agent associated with pyruvate dehydrogenase. Science, 114, 93-94.

Schuhardt, V. T., Rode, L. J., OGlesbt, G., ANd LANKFord, C. E. 1952 Toxicity of ele- mental sulfur for brucellae. J. Bact., 63, 123128.

Simmonds, S., and Fruton, J. S. $1950 a$ Action of penicillin on bacterial utilization of amino acids and peptides. Science, 111, 329.

Simmonds, S., and Fruton, J. S. 19506 The action of penicillin on the growth response of a gram-negative bacillus to amino acids and peptides. Yale J. Biol. Med., 23, 407-426.

Simmonds, S., Harris, J. I., and Fruton, J. S. 1951 Inhibition of bacterial growth by leucine peptides. J. Biol. Chem., 188, 251262.

Simmonds, S., Tatum, E. L., and Fruton, J. S. 1947 The utilization of leucine derivatives by a mutant strain of $E$. coli. J. Biol. Chem., 170, 483-489.

SNell, E. E. 1951 Bacterial nutrition-chemical factors, pp. 214-255. In Bacterial physiology. Edited by C. H. Werkman and P. W. Wilson. Academic Press, New York, N. Y.

SNeld, E. E. 1952 The nutrition of the lactic acid bacteria. Bact. Revs., 16, 235-241.

Snell, E. E., and Broouist, H. P. 1949 On the probable identity of several unidentified growth factors. Arch. Biochem., 23, 326327.

Snell, E. E., Tatum, E. L., and Petergon, W. H. 1937a Growth factors for bacteria. III. Some nutritive requirements for Lactobacillus delbrueckii. J. Bact., 33, 207-225.

Snell, E. E., Strong, F. M., and Peterson, W. H. $1937 b$ Growth factors for bacteria. VI. Fractionation and properties of an accessory factor for lactic acid bacteria. Biochem. J., 31, 1789-1799.

Stone, D., ANd Hoberman, H. D. 1953 Utilization of proline peptides by a prolineless $\mathrm{mu}$ tant of Escherichia coli. J. Biol. Chem., 202, 203-212.

Wood, W. A., and Gunsalus, I. C. 1951 DAlanine formation: A racemase in Streptococcus faecalis. J. Biol. Chem., 190, 403-416. 